\title{
BILANGAN-BILANGAN KELAS DIBAGI TIGA PADA LAPANGAN KUADRATIK RIIL DAN IMAJINER
}

\author{
FARIZI HIZRIAN \\ Program Studi Matematika, \\ Fakultas Matematika dan Ilmu Pengetahuan Alam, Universitas Andalas, \\ Kampus UNAND Limau Manis Padang, Indonesia, \\ farizihizrian@gmail.com
}

\begin{abstract}
Abstrak. Kajian tentang operasi bagi, operasi kongruen modulo $n$, dan operasi bilangan kompleks pada lapangan kuadratik telah banyak dikemukakan dalam berbagai tulisan. Namun tingkat keumuman dari hasil-hasil tersebut masih bervariasi. Pada tulisan ini dikaji penjelasan istilah pada Teorema Pekin untuk diterapkan pada dalil mod 3 dari jumlah kelas lapangan kuadratik riel maupun imajiner dalam bentuk $Q(\sqrt{-q})$.
\end{abstract}

Kata Kunci: Bilangan Kelas, diskriminan, satuan dasar

\section{Pendahuluan}

Banyak pembelajar yang hanya sekedar mengetahui tentang suatu masalah, namun sulit untuk memahami masalah tersebut, apalagi untuk membuktikannya. Sebagai contoh, terkadang anak usia dini yang masih memiliki kemauan yang berlebih, namun belum mampu mengoperasikan pembagian [2]. Di samping itu, banyak juga para penemu terdahulu yang berusaha mengupas setiap masalah di dalam suatu kajian, khususnya di bidang matematika yang berkenaan dengan teoritis. Salah satu topik yang diangkat oleh penulis yaitu masalah operasi bagi, operasi kongruen modulo $n$, operasi bilangan kompleks, satuan, lapangan kuadratik dan nilai diskriminan, serta operasi square free.

Dalam [9] telah ditunjukkan bahwa terdapat bilangan kuadratik tak hingga, yang masing-masing jumlah kelas dibagi oleh bilangan bulat yang diberikan. Dalam [5] dan [3] fakta tersebut telah dibuktikan secara mandiri. Dalam [4], Hartung menunjukkan bahwa terdapat bilangan tak terbatas dari bidang kuadratik imajiner $Q(\sqrt{-q})$ yang bilangan kelasnya habis dibagi tiga, dimana $q \in \mathbb{Z}$ dalam bentuk persegi $\frac{t^{2}-4}{27}$ dan $q \cong 7(\bmod 12)$.

Dalam [6] telah dibuktikan bahwa:

$$
H \cong \frac{-u}{t} h(d)(\bmod 3)
$$

sesuai dengan peneliti sebelumnya.

Pada tulisan ini, $t$ dan $u$ adalah koefisien satuan dasar riil dari $Q(\sqrt{d}) ; H(-q)$ adalah bilangan kelas dari $Q(\sqrt{-q})$; dan $h(d)$ adalah bilangan kelas dari $Q(\sqrt{d})$. 


\section{Beberapa Proposisi pada Operasi Bagi}

Pada kajian ini diberikan beberapa contoh dari bukti yang akan melibatkan operasi bagi. Akan diasumsikan bahwa pernyataan yang berkaitan dengan penjumlahan, perbedaan, dan hasil dari bilangan-bilangan bulat adalah bilangan bulat itu sendiri. Pilih $k_{1}, k_{2} \in \mathbb{N}$, maka $k_{1} \pm k_{2} \in \mathbb{N}$, dan $k_{1} k_{2} \in \mathbb{N}$. Demikian juga halnya dengan bilangan negatif dari bilangan bulat yang lainnya adalah juga suatu bilangan bulat. Ini berarti bahwa untuk setiap $k \in \mathbb{N} \subset \mathbb{Z}$, berlaku juga $-k \in \mathbb{Z}$.

Hasil pertama adalah hal yang berkaitan dengan penjumlahan dari dua bilangan genap akan menjadi bilangan genap pula.

Proposisi 2.1. Misalkan $a, b_{1}, b_{2} \in \mathbb{Z}, a \mid b_{1}$ dan $a \mid b_{2}$, maka $a \mid\left(b_{1}+b_{2}\right)$.

Bukti. Dari asumsi tersebut, $a$ adalah pembagi dari $b_{1}$ dan $b_{2}$. Maka terdapat $k_{1}$, $k_{2} \in \mathbb{Z}$, sedemikian sehingga $a k_{1}=b_{1}$, dan $a k_{2}=b_{2}$. Misalkan:

$$
k=k_{1}+k_{2} \in \mathbb{Z},
$$

maka

$$
a k=a\left(k_{1}+k_{2}\right)=a k_{1}+a k_{2}=b_{1}+b_{2} .
$$

Jadi $a$ adalah pembagi dari $b_{1}+b_{2}$.

Proposisi 2.2. Misalkan $a, b \in \mathbb{Z}$, maka $a \mid b$ jika dan hanya jika $a \mid-b$.

Bukti. $(\Rightarrow)$ Dari asumsi di atas, terdapat $k \in \mathbb{Z}$, sedemikian sehingga $a k=b$. Maka juga terdapat $-k \in \mathbb{Z}$, sedemikian sehingga juga $a(-k)=-a k=-b$. Oleh karenanya $a$ membagi $-b$.

$(\Leftarrow)$ Asumsikan bahwa $a \mid-b$. Dari pembuktian sebelumnya, jelaslah bahwa $a \mid-(-b)=b$.

Proposisi 2.3. Misalkan $a, b_{1}, b_{2} \in \mathbb{Z}$. Jika $a \mid b_{1}$ dan $a \nmid b_{2}$, maka $a \nmid\left(b_{1}+b_{2}\right)$.

Bukti. Akan dibuktikan dengan penyangkalan. Andaikan bahwa $a \mid\left(b_{1}+b_{2}\right)$, maka $a$ adalah sebuah pembagi dari $b_{1}+b_{2}$, dan $b_{1}$. Andaikan juga bahwa $a \mid\left(\left(b_{1}+b_{2}\right)-\right.$ $\left.b_{1}\right)=b_{2}$. Hal ini berlawanan dengan asumsi di awal yang menyatakan bahwa $a \nmid b_{2}$, dan penyangkalan dari pengandaian di atas yang menyatakan bahwa $a \mid\left(b_{1}+b_{2}\right)$, adalah benar. Jadi, ini mengakibatkan $a \nmid\left(b_{1}+b_{2}\right)$.

\section{Suatu Contoh pada Operasi Kongruen Modulo $n$}

Berikut akan diberikan beberapa contoh dan satu proposisi dari operasi kongruen modulo $n$.

Contoh 3.1. Misalkan $a, b, n \in \mathbb{Z}$, dengan $a \cong b(\bmod n)$. Akan ditunjukkan bahwa

$$
a^{k} \cong b^{k}(\bmod n)
$$

untuk setiap $k \in \mathbb{N}$. 
Bukti. Akan diinduksikan terhadap $k \in \mathbb{N}$, dan didefinisikan:

$$
P(k): a^{k} \cong b^{k}(\bmod n) .
$$

(i) Langkah dasar. Ambil $k=1$, maka $a^{1} \cong b^{1}(\bmod n)$; jadi $P(1)$ benar.

(ii) Langkah induksi. Asumsikan bahwa $P(k-1)$ benar. Ini berarti:

$$
a^{k-1} \cong b^{k-1}(\bmod n) \text {. }
$$

(iii) Akan ditunjukkan bahwa benar untuk $P(k)$ yaitu:

$$
a^{k} \cong b^{k}(\bmod n) .
$$

Dari asumsi sebelumnya,

$$
a \cong b(\bmod n) .
$$

Karena hasil dari banyaknya yang kongruen adalah juga kongruen, maka akan ditunjukkan dengan mengalikan pernyataan yang sebangun di atas dengan $a^{k-1}$ pada ruas kiri kongruen, dan mengalikan pernyataan di seberangnya dengan $b^{k-1}$. Sehingga diperoleh:

$$
\left(a^{k-1}\right) \cdot(a) \cong\left(b^{k-1}\right) \cdot(b)(\bmod n) .
$$

Akibatnya,

$$
a^{k} \cong b^{k}(\bmod n) .
$$

Oleh karena itu, dengan menggunakan prinsip induksi matematika, mengakibatkan $P(k)$ benar untuk setiap $k \in \mathbb{N}$.

\section{Teorema Pekin}

Berikut akan diberikan hal pokok yang mendasari skripsi ini, yang merupakan kajian utama yang disajikan dalam bentuk teorema berikut [6]:

Teorema 4.1. Misalkan $d \cong 1(\bmod 4)$ merupakan bilangan bulat pada square free. Jika d dapat dinyatakan dalam bentuk $d=3 q=9 p^{2} m^{2} \mp 4 m$, untuk suatu $p=2 k_{1}+1$ dan $m=2 k_{2}+1 ; k_{1}, k_{2} \in \mathbb{Z}$, maka bilangan kelas $Q(\sqrt{-q})$ habis dibagi tiga.

Bukti. Karena $d \cong 1(\bmod 4)$ maka satuan dasar $Q(\sqrt{d})$, yakni $t$ dan $u$ adalah:

$$
\epsilon=\frac{(t+u \sqrt{d})}{2}>1,
$$

dan diskriminannya adalah $d=3 q$.

Pilih $t \cong \mp 2(\bmod m)$. Ambil $t^{2}-\left(9 p^{2} m^{2} \mp 4 m\right) \cdot u^{2}=4$, dan

$$
t=9 p^{2} m \mp 2,
$$

maka persamaan $t^{2}-\left(9 p^{2} m^{2} \mp 4 m\right) \cdot u^{2}=4$ adalah $t=9 p^{2} m \mp 2$ dan $u=3 p$. Akibatnya satuan dasar dari $Q\left(\sqrt{9 p^{2} m^{2} \mp 4 m}\right)$ adalah:

$$
\epsilon=\frac{\left(9 p^{2} m \mp 2\right)+\left(3 p \sqrt{9 p^{2} m^{2} \mp 4 m}\right)}{2} .
$$


Jadi $h(-q) \cong 0(\bmod 3)$ dari $H \cong \frac{-u}{t} h(d)(\bmod 3)$.

Contoh 4.2. Buktikan bahwa jika $q=27 p^{2}+4$ adalah sebuah bilangan prima, maka $h(-q) \cong 0(\bmod 3)$.

Bukti. Karena

$$
H \cong \frac{-u}{t} h(d)(\bmod 3),
$$

maka $q$ adalah sebuah bilangan persegi bebas yang kongruen dengan $7(\bmod 12)$, $d=3 q$ adalah diskriminan dari lapangan $Q(\sqrt{d})$, dan $\epsilon=\frac{t+u \sqrt{d}}{2}>1$ adalah satuan dasarnya, serta $H$ adalah bilangan kelas dari $Q(\sqrt{-q})$.

Akan ditunjukkan bahwa

$$
\begin{gathered}
\left(27 p^{2}+2\right)^{2}-\left(27 p^{2}+4\right) \cdot 3 \cdot(3 p)^{2}=4, \text { atau } \\
\epsilon=\frac{\left(27 p^{2}+2\right)+3 p \sqrt{3\left(27 p^{2}+4\right)}}{2}
\end{gathered}
$$

adalah persamaan dari lapangan $Q\left(\sqrt{3\left(27 p^{2}+4\right)}\right.$.

Karena $27 p^{2}+4$ adalah bilangan prima dari $q$, maka solusi terkecil adalah :

$$
t^{2}-3\left(27 p^{2}+4\right) u^{2}=4 .
$$

Karena $t \cong \pm 2(\bmod m)$, maka $t=27 p^{2}+2$. Ini berarti $\epsilon$ pada $(4.2)$ adalah persamaan dasar dari $Q\left(\sqrt{3\left(27 p^{2}+4\right)}\right.$, dan nilai dari " $u$ " di $\epsilon$ diberikan oleh $u=3 p$.

Oleh karena itu, Persamaan (4.1) juga memenuhi $h(-q) \cong 0(\bmod 3)$.

\section{Kesimpulan}

Dari uraian di atas, terbukti bahwa

$$
H \cong \frac{-u}{t} h(d)(\bmod 3)
$$

untuk suatu $u=3 p>0 ; u, t, p \in \mathbb{R} ; t \neq 0, d=3 q ; d, q \in \mathbb{C}$.

\section{Daftar Pustaka}

[1] Dunia Matematika Diskriminan.htm (27 Januari 2015).

[2] Morris, Dave Write dan J. Morris. 2006. Proofs and Concepts. State University of New York, 171-176.

[3] N.C. Ankeny dan S. Chowla. On The Divisibility of The Class Number of Quadratic Fields. Pasific J. of Math. 5, (1955), 321-324.

[4] P. Hartung. Explicit Construction of A Class of Infinitely Many Imaginary Quadratic Fields Whose Class Number is Divisible by 3. Journal of NumberTheory 6, (1974), 279-281.

[5] P. Humbert. Sur Les Nombresde Classes de Certain Corps Quadratiques. Comment.Math.Helv.12, (1939-40) 233-245, also 13 (1940-41).

[6] Pekin, Ayten. On Imaginary Quadratic Fields whose Class Numbers are Divisible by 3. Int. J. Contemp. Math. Sciences, Vol. 3, (2008), 327-329.

[7] Quadratic Field-Wilkipedia, the free enclyclopedia.htm (28 Januari 2015). 
Bilangan-Bilangan Kelas Dibagi Tiga 99

[8] Square-free integer-Wilkipedia, the free enclyclopedia.htm (28 Januari 2015).

[9] Tr. Nagel. Parametrization of The Quadratic Fields Whose Class Numbers Are Divisible by Three. J. Number Theory, 80 (2000), 209-217. 